\title{
The Crisis of Democracy Which Crisis? Which Democracy?
}

\author{
Selen A. Ercan and Jean-Paul Gagnon
}

\begin{abstract}
D Abstract: The introductory article to this special issue highlights three fundamental yet often neglected questions related to the current diagnosis of a crisis of democracy: What is meant by the term "crisis"? Which democracy is in crisis? And what, if anything, is "new" about the current crisis of democracy? We answer these questions by considering the multi-vocal contribution of purposefully curated short articles in this special issue. We argue that when engaging with the "crisis of democracy" diagnosis, it is important to unpack not only the normative presumptions one has in relation to what democracy is and should be, but also the recent transformations in the way politics is understood and practiced in contemporary societies.
\end{abstract}

Keywords: crisis, democracy, democratic crisis

\section{Introduction}

In recent years, the diagnosis on the crisis of democracy has received renewed attention in both scholarly literature and popular commentary. Democracy is claimed to be in crisis as a result of various factors including: high levels of citizen disaffection with politics (Campus and Andre 2014); the gross lack of political literacy (Rapeli 2013); low levels of satisfaction and trust in governments and politicians (Hay and Stoker 2009; Warren 2009); the decline in membership of political parties (Whiteley 2009); the increasing power of actors without electoral accountability, such as transnational institutions, central banks, or regulatory bodies (Vibert 2007); the failure, or ineffectiveness, of representation (Shields 2006); and the proliferation of complex governance arrangements that evade accountability and transparency (Runciman 2014).

This list includes only a small part of the "democracy in crisis" literature, but its length prompts us to ask why such a high level of diversity exists in this particular area of discourse. One possible answer is that 
both "crisis" and "democracy" are contested terms, which means that they can be used in diverse contexts for different purposes. The ability to apply widely both terms together has, however, manifested concerns about whether this diversity is obscuring rather than enlightening our understanding of the crisis, or crises, of democracy or democracies. To be able to specify what exactly is at stake, we need to engage with the following fundamental yet often neglected questions: What exactly is meant by the term "crisis"? Which "democracy" is in crisis? And what, if anything, is "new" about the current crisis of democracy? These questions draw our attention to the importance of context in any political analysis (Tilly and Goodin 2006) and invite us to think harder about the questions of when, where, and on what premises democracy is claimed to be in crisis.

This special issue brings together a number of purposefully curated short articles that engage these fundamental questions. The format of numerous articles is a deviation from Democratic Theory's standard special issue style of longer essays in order to include a larger number of contributions from a wider range of angles. This format goes hand in hand with the purposes of this issue, which are to capture the multiple perspectives on the concepts of democracy and crisis and to present the variety of ways in which these concepts can be theoretically articulated and empirically studied.

This special issue reflects and builds upon discussions that took place during a two-day international symposium on the crisis of democracy that was held in the middle of March 2014 at the Institute for Governance and Policy Analysis at the University of Canberra. The discussions during this symposium revealed a number of central themes with respect to the current crisis diagnosis, its empirical measurement, and its possible remedies. The two contested terms, "democracy" and "crisis," when paired, required paying particular attention to various contextual factors that gave these terms their particular meaning. In each case, when a particular crisis of democracy was interrogated, contributors at the symposium found that what was being discussed was a particular type of democracy, or one of its constitutive elements, that was encountering a specific problem that generated either an acute or chronic form of crisis. Whereas in the 1940s democracy was itself at risk of extinction and in the 1970s representative democracy encountered its first major existential crisis, crises of democracies today are more varied and nuanced.

Our purpose in this Introduction is not to verify or falsify the current crisis diagnosis. In other words, we do not seek to provide a definitive answer to the question of whether democracy is in crisis or not. Rather, our aim is to draw attention to various ways of approaching this ques- 
tion in both theory and practice. A central task for this Introduction is then to capture the flavor of this complexity. By asking "which crisis?" and "which democracy?" we seek to draw attention to the differences in the normative underpinnings of different democratic approaches, and to show how these differences affect what one defines as an empirically observable manifestation of "crisis." Simply put, one person's idea of a democratic act might be viewed by another as counter-democratic or as a contributing factor to the crisis. For example a radical democrat could view the occupation of a busy inner-city street by protesters unhappy with a government policy as an act of democracy. But an adherent to liberal representative democracy could see this act of protest as a weakening of representation and as un-democratic as it is infringing upon the liberty of, in this example, individual drivers. Like the term "democracy," "crisis" can have different meanings. Crisis can be acute or chronic. Or the claim can be overblown as the term might point to trouble in a particular institution - rather than a system of democracy as a whole.

In our view, this issue seeks to make sense of the crisis diagnosis within a context of broader transformations at both local and global levels which have strongly influenced the theory and practice of democracy in recent years. This context includes factors such as: the shift from government to governance (Shore 2011; Fawcett, this issue); the depoliticization of policy issues in which unelected managers or experts dominate (Marsh, this issue; Radaelli 2009); the ongoing risk of democrats undoing democracy (Chou 2014; Tormey, this issue); the rise of neoliberalism as a political doctrine that reinforces a minimalist vision of the public sphere and democracy (Della Porta 2013); the emergence of issue-specific, rather than ideology-driven, politics (Taylor 2007); the rise of new forms of collective action driven, in part, by new information technologies (Bennett and Segerberg 2012); the proliferation of many media innovations that characterize the current state of "communicative abundance" (Keane 2013); and the recent spread of democratic innovations and deliberative experiments in Western liberal as well as developing countries (Smith 2009).

These developments affect how we understand democratic politics, including its successes, its failures and symptoms of malfunctioning. It is, thus, important to make sense of the crisis diagnosis not in a vacuum but in the context of broader transformations and trends affecting contemporary politics and of the forces driving them. The task of contextualising the current democratic crisis diagnosis brings us back to our three fundamental questions. 


\section{Which Crisis?}

As we recognize that crisis is not a homogeneous phenomenon, but rather a term used to identify a very large number of phenomena, we begin by interrogating its defining characteristics in the context of debates about the state of democracy. As Reinhart Koselleck and Michaela Richter (2006) note in their historical analysis of the term, "crisis" originally comes from ancient Greek and imposes choices between stark alternatives, such as just or unjust, right or wrong, life or death. In classical Greek, the term was central to politics and meant "decision" in the sense of reaching a verdict or judgement. Later the term spread to almost all economic, social, political, and personal aspects of life with a relatively broad spectrum of meanings. Given the multiple meanings attached to the term crisis, some scholars denied its utility for any political or economic analyses. Joseph Schumpeter, for example noted in his analysis of business cycles, "We shall not give any technical meaning to the term crisis but only to prosperity and depression" (Schumpeter 1939: 5, cited in Koselleck and Richter 2006: 397). Yet for others the term crisis proved not only to be useful, but also positive, entailing the prospects for transformation towards something better (Gijsenbergh et al. 2012).

As earlier noted, in the context of democracy studies, "crisis" has always been a powerful term depicting the state of democracy particularly in the Anglophone West (Runciman 2013). Yet it has had different connotations. For example, in 1975, a group of prominent social scientists commissioned by the Trilateral Commission to draft a report about the state of democracy used the term "crisis" to problematize the presence of too much democracy (Crozier, Huntington, and Watanuki 1975). These authors argued that intellectuals and the critical media increasingly undermined democracies but also that different social groups and civil society movements were demanding greater and more meaningful participation. Not only was the practice of democracy, for the 1970s, in crisis but so too was its very meaning. Discussions focused on whether too many practices of democracy can pose a problem for a democratic state, whether a state can be democratic when its own people are not able to participate effectively, and whether the long-standing practice of representative democracy is the only way to institutionalize democracy at the level of the nation-state.

Drawing on a recent example, crisis is used to identify the reversal of democracy as problematic. Samuel Huntington's (1991) third wave thesis serves as the basis to claim that a fourth wave of democracy has been sweeping the far east of Europe, the Middle East and North Africa for the last twenty-five or so years (McFaul 2002, Way 2005, Howard and Hussain 
2013). But, just as a number of young democracies reversed or certain transitions to democracy halted during the third wave, most of those polities in the putative fourth wave are also reversing or halting into types of mixed regimes (Egypt serves as a good example; see Isakhan 2014: 149-163 for more). They are, thus, "in crisis." The task is to figure out which parts of these reversals are becoming diagnosed as crises (Merkel, this issue; Stoker and Evans, this issue). In these cases, a "crisis" indicates problems with inter-party competition, with a balance of power between the institutions of the state, with the formulation and implementation of new constitutions, with despondent electorates, and with electoral systems.

\section{Which Democracy?}

Democracy is an essentially contested concept. The word is prefaced by over 500 adjectives (see Gagnon et al. 2014), such as liberal, representative, deliberative, feminist, and radical. Thus we must examine what kind of democracy we have in mind when criticizing its current flaws (Gagnon 2014). Most of the literature confirming the current crisis diagnosis seems to take the traditional conception of representative democracy as a normative standard. Scholars advocating different notions of democracy come to diverse, if not contradictory, conclusions about the state of democracies and the conditions for democratization, depending on whether their focus is on conventional or alternative sites and mechanisms for democracy (Dryzek 2009). The way various scholars interpret the emergence of the Occupy type of new social movements around the world provides an example (Chou 2014a). For some scholars, the rise of such movements and unconventional forms of participation epitomize the growth of political competences, particularly among youth. They represent new opportunity structures for extending the forms of legitimate political involvement beyond the vote (Della Porta 2013: 58; Prentoulis and Thomassen 2013: 177; Tormey, this issue). As such, they contribute to the revival of democracy, especially its participatory and deliberative variant (Mendonca and Ercan, forthcoming). Not all scholars find this claim convincing. For some the new social movements are clear manifestations of political alienation and populism incited by democracy's failures rather than by its successes (Kaldor 2013; Grattan 2012; Fukuyama 2012).

The broader point here is that advocates of one type might cry crisis if a different form of democracy is being exercised since the advocates might see this as an abrogation of their idea of democratic validity. There is, for instance, a tension between "thick" participatory accounts of de- 
mocracy and "thin" electoral understandings of democracy (Della Porta 2013). Similarly, a deliberative democrat would evaluate the success or failure of a democracy not in and around the ballot box or according to the aggregation of the votes coming out of this box only. She would rather look for the opportunities provided to those affected by a particular decision to participate in the making of those decisions (see, for example, Chaskin, Khare, and Joseph 2012). This is not to say that a deliberative democrat would not be interested in what the majority thinks and votes for; she would. Yet, when seen from a deliberative democratic perspective, unless the decision of the majority is coupled with prior debate and deliberation on the issue at stake, it can hardly claim a collective democratic legitimacy.

So, what may seem perfectly fine from a liberal electoral perspective can easily be defined as a crisis of democracy when seen from an alternative perspective of democracy. Take, for example, referendums which are usually thought to have some sort of "natural" affinity with democracy in its most direct form. However, when seen from a deliberative perspective, there are good reasons to be cautious about the democratizing potential of referendums. They tend to drive out the deliberative element in policy making, reduce the complex issues to "yes or no" questions easily and thus serve to justify the "tyranny of the majority." They privilege the weight of numbers underpinned by an aggregative logic, rather than the weight of arguments as suggested by deliberative logic and thinking.

To be clear, the definition of what indicates the success, crisis, or failure of democracy depends not only on the normative democratic approach one takes but also on socio-political and historical factors that give both democracy and crisis, and their coupling a particular meaning. This brings us to the last question that we raised at the outset of this article: what is new about the current crisis of democracy diagnosis? We think that while the theoretical approach provides an angle through which we can define what exactly is in crisis (e.g. representation, participation, conventional institutions), a comparison of crisis diagnosis across time helps us specify the peculiarities, if any, of the current crisis of democracy.

\section{What is New about the Current "Crisis of Democracy" Diagnosis?}

Arguably, there is nothing new about the democratic crisis diagnosis. In other words, crisis has never been the exception to the rule; rather, it is an inherent feature of democracy and may even be seen as a sign that it is functioning. The argument here is that democracy is fundamentally a 
normative and unfinished project. In fact it is this unfinished and openended aspect that serves as the lifeblood of democracy. If it was possible to set things in stone and make collective decisions once and for all, there would be neither democracy nor crisis. Yet although crisis is an inherent feature of democracy, there are important differences between what were seen as the underlying reasons of legitimacy and democratic crisis in the past versus those we see today (Stoker and Evans, this issue).

Take for example two particular time periods from the past, the 1940s and 1970s, when a similar diagnosis dominated both the academic and public discourse. ${ }^{1}$ In the case of the 1940s, national representative democracies were under threat from totalitarian ideologies like fascism or communism, which reinforced the practice of a state's arbitrary and coercive power. In fact, the representative form of democracy came close to extinction during World War II, paradoxically, in the name of fostering more or "true" democracy (Schmitt 1996).

Compared to the 1940s, the nature of the crisis of democracy in the 1970s was different. The crisis did not come from threatening military expansionisms; it came rather from an internal change to the conventional practices of democracy occurring within the state itself. Certain walls existed around procedures like voting and policy areas like foreign affairs; and a number of institutions and members of parliament were securitized, hidden away in part through secrecy and a political party's interest in maintaining the status quo, which limited the participation of individual citizens. People wanted to do more, and do differently, than just vote, join a political party, and write or telephone their district's representatives. Democratic states increasingly looked like they needed democratization to accommodate the growth of an increasingly democratic public sphere. In the 1970s, the democratic crisis was understood in terms of system crisis, which manifested itself as legitimation crisis (Habermas 1975). Also, in the 1970s economic failure allied more strongly with crisis of democracy. Inflation, for instance, was presented as one of the main factors for undermining democracy (Runciman 2013: 171).

Compared to the 1970s, today we hear less about economic factors in the talk of democratic crisis. This is not to say that such factors play a less important role (Marsh, this issue), but they seem to lose their overarching explanatory power. Similarly, we do not hear much about the system level legitimation crisis predicted in the 1970s, most notably by Jürgen Habermas. As Mark Warren rightly notes, today:

the broad legitimation pressures show up not as a general system crisis, but rather issue by issue and policy by policy, in protests over airport expansion, medical coverage, poverty issues, changes in regulation of genetically-modified organisms, forest management, struggles over 
neighbourhood development, energy pricing, and so on. So rather than general system crisis, we have something like pluralized governability, driven by functional incapacities of government agencies, as well as overlapping or competing jurisdictions, or failures to anticipate spillover consequences and linkages among issues. (Warren 2009: 7)

This shows us how the reasons for democratic crisis change along with the shifts in the way contemporary politics is understood and practiced, which is partly a consequence of the broader transformations discussed above. One clear message that extends from Warren's observation is that if crisis is an inherent feature of democratic politics, irrespective of the form such politics may take, what we need is a more reflexive democracy a type of democracy that continuously confronts its own limits and logics of exclusion. The individual contributions of this special issue offer new ways of defining such limits and discuss their implications for the theory and practice of democracy.

\section{This Special Issue}

This special issue consists of articles approaching the contemporary crisis of democracy from a variety of theoretical and empirical perspectives. The issue is composed of three sections. The first section focuses on the question of whether democracy is in crisis and points to the various limitations and paradoxes of contemporary democratic theory (Merkel, Stoker and Evans, Marsh, McCaffrie and Akram). The second section offers a critical engagement with the question of which crisis. Articles here focus on the various manifestations of the crisis of democracy and discuss its conceptual remedies (Bang, Fawcett, Navarria, Jensen, Felicetti). Finally, the third section captures different forms of democracy that have encountered crisis and illustrates how this looks in practice by drawing on a variety of case studies from around the world (Tormey, Curato, Tamura and Kobayashi, Dare, Monro). These contributions fulfil the aims of this special issue by deepening our understanding of the variety of phenomena and context-dependant nuances involved in the diagnoses of "democracy in crisis."

\section{NOTES}

1. For the crisis diagnosis in 1940s, see for example, Capoccia 2007, Taylor 1999, and Smith 1995; and for the democratic crisis in 1970s, see for example, Crozier, Huntington and Watanuki 1975, Habermas 1975). 


\section{REFERENCES}

Bennett, W. Lance, and Alexandra Segerberg. 2012. "The Logic of Connective Action. Digital Media and the Personalization of Contentious Politics." Information, Communication \& Society 15 (5): 739-768.

Capoccia, Giovanni. 2007. Defending Democracy: Reactions to Extremism in Interwar Europe. Baltimore: Johns Hopkins University Press.

Campus, Andre Santos, and José Gomes André. 2014. Challenges to Democratic Participation. Antipolitics, Delibertive Democracy and Pluralism. Lanham: Lexington Books.

Chaskin, Robert, Amy Khare, and Mark Joseph. 2012. "Participation, Deliberation, and Decision Making: The Dynamics of Inclusion and Exclusion in MixedIncome Developments." Urban Affairs Review 48 (6): 863-906.

Chou, Mark. 2014. "Democrats against Democracy.” Cultural Politics 10 (2): 163-181.

Chou, Mark. 2014a. "From Crisis to Crisis: Democracy, Crisis and the Occupy Movement.” Policial Studies Review doi:10.1111/1478-9302.12070/abstract

Crozier, Michel J., Samuel P. Huntington, and Joji Watanuki. 1975. The Crisis of Democracy. Report on the Governability of Democracies to the Trilateral Commission. New York: New York University Press.

Della Porta, Donatella. 2013. Can Democracy be Saved? Cambridge: Polity.

Dryzek, John. 2009. “Democratization as Deliberative Capacity Building." Comparative Political Studies 42 (11): 1379-1402.

Fukuyama, Francis. 2012. "The Future of History: Can Liberal Democracy Survive the Decline of the Middle Class?" Foreign Affairs 91 (1): nn.

Gagnon, Jean-Paul. 2014. Democratic Theorists in Conversation: Turns in Contemporary Thought. Basingstoke, UK: Palgrave Macmillan.

Gagnon, Jean-Paul, Mark Chou, Selen A. Ercan, and Giovanni Navarria. 2014. “Democratic Theories Database.” Working Paper \#1, Australian Catholic University Research Node in the Sydney Democracy Network. http://sydneydemocracy network.org/wp-content/uploads/2014/11/Democratic-Theories-Database.pdf

Gijsenbergh, Joris, Saskia Hollander, Tim Houwen, and Wim de Jong, eds. 2012. Creative Crisis of Democracy. Brussels: Peter Lang.

Grattan, Laura. 2012. "Pierre Bourdieu and Populism: The Everyday Politics of Outrageous Resistance.” The Good Society 21 (2): 194-218.

Habermas, Jürgen. 1975. Legitimation Crisis. Boston: Beacon Press.

Hay, Colin, and Gerry Stoker. 2009. "Revitalising Politics: Have We Lost the Plot?” Representation 45 (3): 225-236.

Howard, Philip N., and Muzzamil M. Hussain. 2013. Democracy's Fourth Wave? Digital Media and the Arab Spring. Oxford: Oxford University Press.

Huntington, Samuel. 1991. The Third Wave: Democratization in the Late Twentieth Century. Norman: University of Oaklahoma Press.

Isakhan, Benjamin. 2014. "Democratising Governance after the Arab Revolutions." Pp. 149-163 in Democracy and Crisis: Democratising Governance in the Twenty-First Century, ed. Benjamin Isakhan and Steven Slaughter. Basingstoke: Palgrave Macmillan.

Kaldor, Mary. 2013. “The ‘Bubbling Up’ of Subterranean Politics in Europe.” Journal of Civil Society 9 (1): 78-99. 
Keane, John. 2013. Democracy and Media Decadence. Cambridge: Cambridge University Press.

Koselleck, Reinhart, and Michaela W. Richter. 2006. “Crisis.” Journal of the History of Ideas 67 (2): 357-400.

McFaul, Michael. 2002. "The Fourth Wave of Democracy and Dictatorship: Noncooperative Transitions in the Postcommunist World." World Politics 54 (2): 212-244.

Mendonca, Ricardo F., and Selen A. Ercan. forthcoming. "Deliberation and Protest: Strange Bedfellows? Revealing the Deliberative Potential of 2013 Protests in Turkey and Brazil." Policy Studies.

Prentoulis, Marina, and Lasse Thomassen. 2013. "Political Theory in the Square: Protests, Representation and Subjectification." Contemporary Political Theory 12 (3): 166-184.

Radaelli, Claudio. 2009. "How Bureaucratic Élites Imagine Europe: Towards Convergence of Governance Beliefs?” Journal of European Public Policy 16 (7): 971-989.

Rapeli, Lauri. 2013. The Conception of Citizen Knowledge in Democratic Theory. London: Palgrave Macmillan.

Runciman, David. 2013. “The Crisis of British Democracy. Back to the '70s or Stuck in the Present?" Juncture 20 (3): 169-177.

Runciman, David. 2014. The Confidence Trap: A History of Democracy in Crisis from World War I to the Present. Princeton: Princeton University Press.

Schmitt, Carl. 1996. The Concept of the Political. Chicago: The University of Chicago Press.

Shields, James G. 2006. "Political Representation in France: A Crisis of Democracy?” Parliamentary Affairs 59 (1): 118-137.

Shore, Cris. 2011. “'European Governance’ or Governmentality? The European Commission and the Future of Democratic Government." European Law Journal 17 (3): 287-303.

Smith, Graham. 2009. Democratic Innovations. Designing Institutions for Citizen Participation. Cambridge: Cambridge University Press.

Smith, Tony. 1995. America's Mission: The United States and the Worldwide Struggle for Democracy in the Twentieth Century. Princeton: Princeton University Press.

Taylor, Charles. 2007. “Cultures of Democracy and Citizen Efficacy.” Public Culture 19 (1): 117-150.

Taylor, Philip M. 1999. British Propaganda in the $20^{\text {th }}$ Century: Selling Democracy. Edinburgh: Edinburgh University Press.

Tilly, Charles, and Robert E. Goodin. 2006. "It Depends.” Pp. 3-32 in The Oxford Handbook of Contextual Political Analysis, ed. Charles Tilly and Robert E. Goodin. Oxford: Oxford Univeristy Press.

Vibert, Frank. 2007. The Rise of the Unelected. Cambridge: Cambridge University Press.

Warren, Mark E. 2009. “Governance-driven Democratization.” Critical Policy Studies 3 (1): 3-13.

Way, Lucan. 2005. "Authoritarian State Building and the Sources of Regime Competitiveness in the Fourth Wave: The Cases of Belarus, Moldova, Russia, and Ukraine.” World Politics 57 (2): 231-261.

Whiteley, Paul. 2009. "Where Have All the Party Members Gone? The Dynamics of Party Membership in Britain.” Parliamentary Affairs 62 (2): 242-257. 